\section{LITERASI KEUANGAN}

(TEORI DAN IMPLEMENTASINYA)

Literasi keuangan merupakan sesuatu yang diperlukan oleh setiap orang agar mampu menerapkan skala prioritas dalam mengelola keuangannya dan bisa membedakan kebutuhan dan keinginan. Literasi keuangan juga menjadi hal yang sangat penting bagi pemahaman dan pengetahuan dalam mengelola keuangannya dengan bijak. Pentingnya literasi keuangan menjadi tak terelakkan ketika situasi ekonomi saat ini (dimasa pandemic covid 19) sedang dipertaruhkan. Di masa depan, Indonesia memiliki banyak peluang emas untuk memanfaatkan keuntungan ekonominya melalui pemanfaatan bonus demografis dan tren fintech yang berkembang. Namun, di era milenial ini belum memiliki kemampuan yang memadai dalam memanfaatkan peluang ini. Berdasarkan data Otoritas Jasa Keuangan (OJK), indeks literasi keuangan yang baru mencapai $38,03 \%$ (0JK, 2019) membuat peluang tersebut tidak dapat dimanfaatkan secara maksimal. Maka dari itu, masyarakat harus memiliki pengetahuan dan pemahaman yang cukup serta dapat memanfaatkan peluang yang ada. Hal tersebut dapat disimpulkan bahwa seluruh masyarakat indonesia memang masih belum mempunyai tingkat literasi keuangan yang cukup atau tinggi. Perkembangan per kapita pada negara ini wajib diiringi dengan literasi keuangan yang signifikan dan harus diimbangi dengan pemberian edukasi yang memadai agar tingkat literasi keuangan masyarakat Indonesia terhadap industrijasa keuangan juga semakin meningkat.

Dalam upaya memberikan pemahaman dan edukasi yang lebih luas, buku Literasi Keuangan (Teori Dan Implementasinya) ini disusun dalam 9 (sembilan) bab yaitu adanya pembaharuan baru yakni pada bab 1 dijelaskan mengenai literasi keuangan. Bab 2 menjelaskan mengenai pentingnya literasi keuangan untuk meningkatkan kemampuan pengelolaan keuangan masyarakat. Bab 3 menjelaskan mengenai faktor - faktor yang mempengaruhi literasi keuangan. Bab 4 menjelaskan mengenai pengetahuan masyarakat mengenai sektor jasa keuangan. Bab 5 menjelaskan mengenai dampak rendahnya literasi keuangan. Bab 6 menjelaskan mengenai penggunaan fintech masyarakat di era digital. Untuk bab 7 khusus menjelaskan mengenai implementasi literasi keuangan dengan isu-isu saat ini. Bab 8 menjelaskan mengenai kuisioner literasi keuangan dan faktornya. Bab 9 hanya memberikan kesimpulan. Buku ini pula di peruntukkan di kalangan masyarakat luas, tidak hanya bagi dosen, mahasiswa, lembaga pemerintahan tapi juga bagi masyarakat umum. Selamat membaca, semoga bermanfaat.
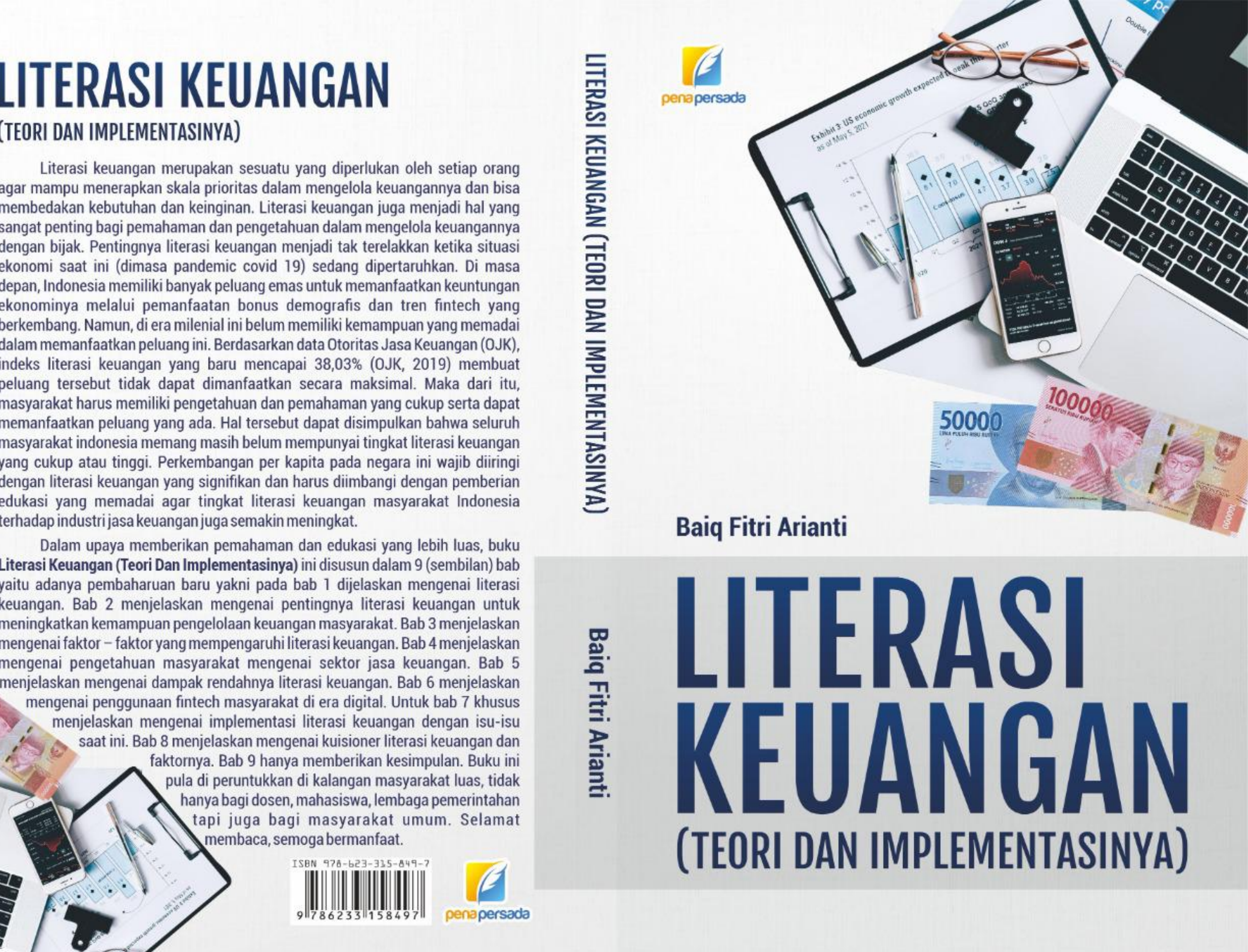

\section{Baiq Fitri Arianti}

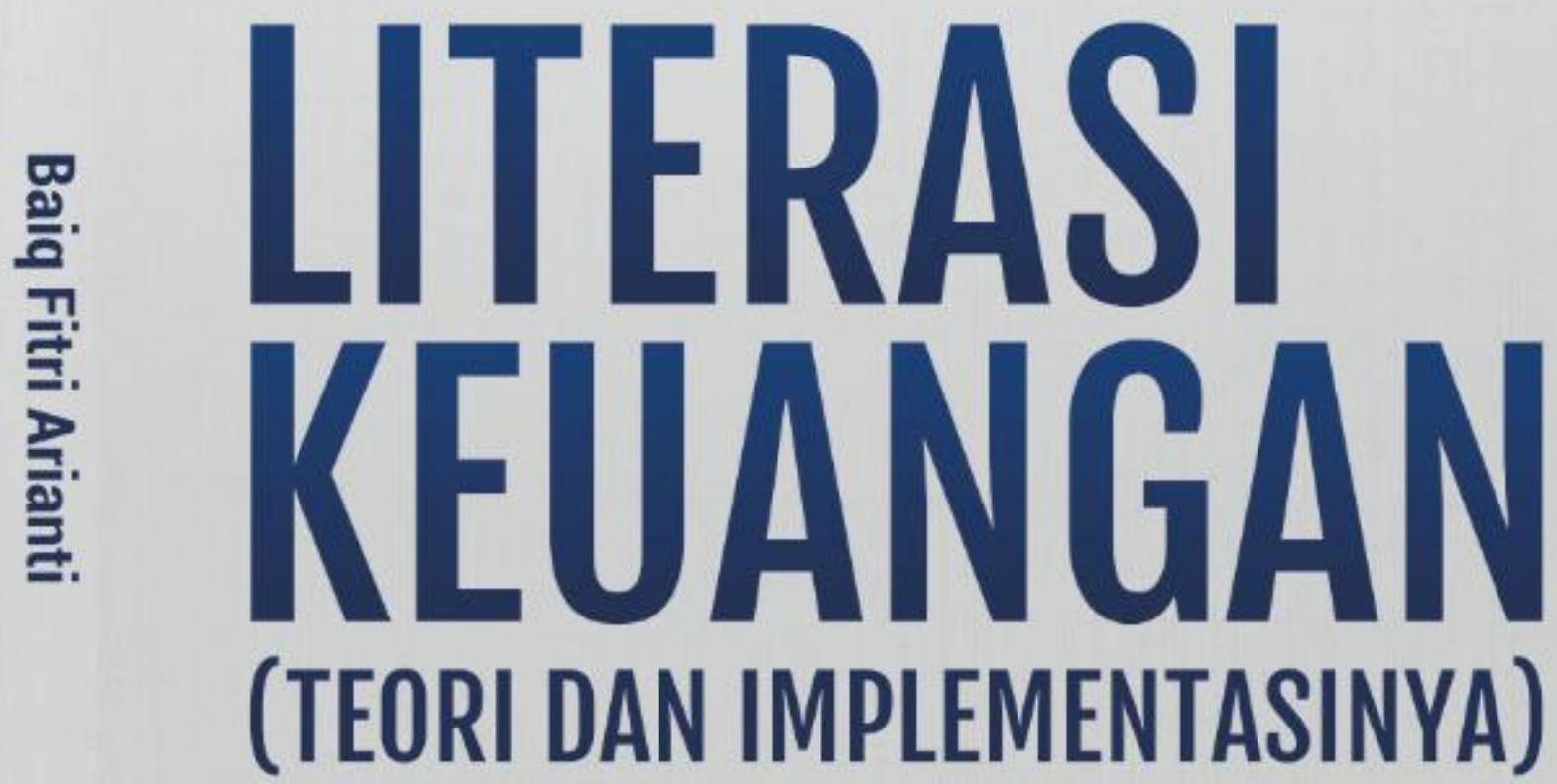




\section{LITERASI KEUANGAN \\ (TEORI DAN IMPLEMENTASINYA)}

BAIQ FITRI ARIANTI

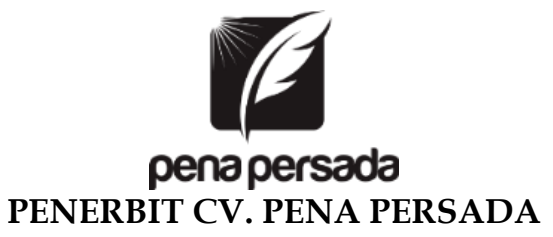




\title{
LITERASI KEUANGAN \\ (TEORI DAN IMPLEMENTASINYA)
}

\author{
Penulis: \\ Baiq Fitri Arianti
}

ISBN: 978-623-315-849-7

\section{Editor:}

Wiwit Kurniawan

\section{Design Cover:}

Retnani Nur Briliant

\author{
Layout: \\ Nisa Falahia

\section{Penerbit CV. Pena Persada} \\ Redaksi:
}

Jl. Gerilya No. 292 Purwokerto Selatan, Kab. Banyumas

Jawa Tengah

Email: penerbit.penapersada@gmail.com

Website: penapersada.com Phone: (0281) 7771388

\section{Anggota IKAPI}

All right reserved

Cetakan pertama: 2021

Hak Cipta dilindungi oleh undang-undang. Dilarang memperbanyak karya tulis ini dalam bentuk apapun tanpa izin penerbit 


\section{KATA PENGANTAR}

Puji syukur saya panjatkan kepada Tuhan Yang Maha Esa, karena atas berkat dan rahmat-Nya, saya dapat menyelesaikan buku ini. Penulisan buku merupakan buah karya dari pemikiran penulis yang diberi judul "Literasi Keuangan Teori dan Implementasinya". Saya menyadari bahwa tanpa bantuan dan bimbingan dari berbagai pihak sangatlah sulit bagi saya untuk menyelesaikan karya ini. Oleh karena itu, saya mengucapkan banyak terima kasih pada semua pihak yang telah membantu penyusunan buku ini. Sehingga buku ini bisa hadir di hadapan pembaca.

Kajian dalam buku ini bertujuan untuk mengetahui bahwa literasi keuangan merupakan kemampuan dalam membuat penilaian informasi dan mengambil keputusan yang efektif tentang penggunaan dan pengelolaan uang. Literasi keuangan juga merupakan kombinasi dari kemampuan individu, pengetahuan, sikap dan akhirnya perilaku individu yang berhubungan dengan uang serta bisa membedakan kebutuhan dan keinginan. Jika seseorang memiliki literasi keuangan yang rendah maka pengetahuan tentang keuangan juga rendah, hal ini sangat penting bagi seorang individu agar tidak salah dalam mengelola keuangannya. Pengetahuan tentang keuangan yang kurang mengakibatkan kerugian bagi individu karena terjadinya kesalahan dalam mengelola keuangannya seperti kesalahan dalam penggunaan kredit/utang yang tidak tepat, penggunaan kartu kredit yang tidak bijak, tidak adanya perencanaan keuangan yang baik dan sebagainya. Keterbatasan financial dapat menyebabkan stress dan rendahnya kepercayaan diri. Literasi keuangan yang kian mendapat perhatian terutama di negara - negara maju semakin menyadarkan kita betapa pentingnya "melek" keuangan. Maka dari itu pihak - pihak yang terkait terutama kepada pihak OJK dan lembaga keuangan lainnya harus melakukan edukasi secara merata dibidang keuangan kepada masyarakat indonesia bukannya hanya pada masyarakat kota namun juga 
pada masyarakat yang terpencil agar mereka dapat mengelola keuangan secara cerdas, sehingga rendahnya pengetahuan dan pemahaman tentang industri keuangan dapat diatasi serta masyarakat tidak mudah tertipu dengan produk - produk investasi yang menawarkan keuntungan tinggi dalam jangka pendek tanpa mempertimbangkan resikonya. Pengetahuan dan pemahaman tentang keuangan pribadi dibutuhkan individu agar dapat membuat keputusan yang benar dalam keuangan, sehingga mutlak diperlukan setiap orang dapat secara optimal menggunakan instrumen - instrumen serta produk keuangan yang tepat. Kurangnya pengetahuan literasi keuangan menjadi masalah serius dan menjadi tantangan besar bagi masyarakat indonesia.

Penulis menyadari bahwa buku ini masih jauh dari kesempurnaan. Oleh karena itu kritik dan saran yang membangun sangat dibutuhkan guna penyempurnaan buku ini. Akhir kata saya berharap Tuhan Yang Maha Esa berkenan membalas segala kebaikan semua pihak yang telah membantu. Semoga buku ini akan membawa manfaat bagi pengembangan di bidang ilmu ekonomi, akuntansi keuangan dan manajemen keuangan.

Penulis,

Baiq Fitri Arianti 


\section{DAFTAR ISI}

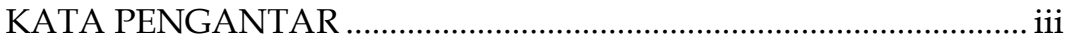

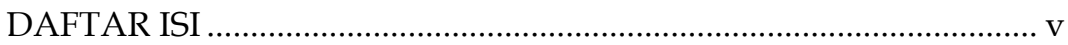

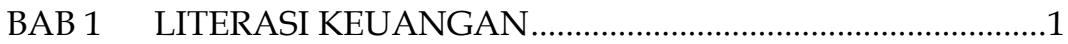

BAB 2 PENTINGNYA LITERASI KEUANGAN UNTUK MENINGKATKAN KEMAMPUAN PENGELOLAAN KEUANGAN MASYARAKAT ............................................14

BAB 3 FAKTOR - FAKTOR YANG MEMPENGARUHI LITERASI KEUANGAN.....................................................18

BAB 4 PENGETAHUAN MASYARAKAT MENGENAI

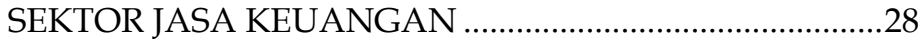

BAB 5 DAMPAK RENDAHNYA LITERASI KEUANGAN .........41

BAB 6 PENGGUNAAN FINTECH MASYARAKAT DI ERA

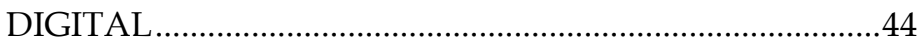

BAB 7 IMPLEMENTASI LITERASI KEUANGAN ..........................56

BAB 8 KUISIONER LITERASI KEUANGAN DAN FAKTORNYA 231

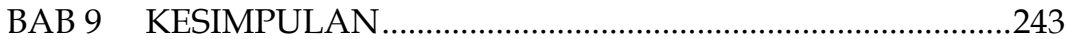

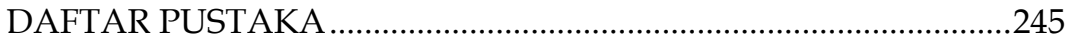

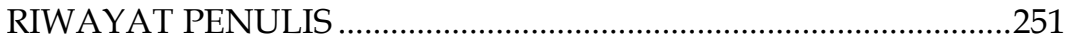




\section{LITERASI KEUANGAN (TEORI DAN IMPLEMENTASINYA)}




\section{BAB 1 \\ LITERASI KEUANGAN}

Permasalahan perekonomian di dunia semakin kompleks, dimana hal tersebut menjadikan masyarakat menyadari akan pentingnya literasi keuangan yang baik. Masyarakat akan terus mencari solusi atas permasalahan ekonomi yang dihadapi agar dapat memenuhi kebutuhannya. Meningkatnya berbagai macam produk dan jasa yang ditawarkan di pasar. Hal ini membuat masyarakat yang diposisikan sebagai konsumen terkadang membeli tanpa memperhatikan prinsip keuangan. Prinsip keuangan yang dimana membeli produk atau jasa sesuai dengan apa yang dibutuhkan bukan produk atau jasa yang diinginkan, hal inilah yang sering dilalaikan oleh para konsumen sehingga lebih memilih untuk membeli sesuatu yang diinginkan bukan sesuatu yang dibutuhkan.

Literasi keuangan yang erat kaitannya dengan manajemen keuangan dimana semakin tinggi tingkat literasi keuangan seseorang maka makin baik pula manajemen keuangan seseorang tersebut. Manajemen keuangan pribadi merupakan salah satu aplikasi dari konsep manajemen keuangan pada level individu. Manajemen keuangan yang meliputi aktivitas perencanaan, pengelolaan dan pengendalian keuangan, sangatlah penting untuk mencapai kesejahteraan finansial.

Literasi keuangan atau melek keuangan mengacu pada kemampuan atau tingkat pemahaman/pengetahuan seseorang atau masyarakat tentang bagaimana uang bekerja. Namun nyatanya masyarakat Indonesia juga cenderung semakin konsumtif. Hal itu tercermin dari menurunnya Marginal Propensity to Save (MPS) dan meningkatnya Marginal Propensity to Consumption (MPC) selama lima tahun terakhir. Oleh sebab itu tingkat konsumtif masyarakat saat ini semakin tinggi sehingga masyarakat semakin tidak rasional dalam membeli kebutuhannya baik kebutuhan konsumsi makanan maupun non makanan. 
Pengelolaan keuangan yang efektif dibutuhkan dalam kehidupan sehari - hari untuk kebijakan pengambilan keputusan keuangan. Perilaku keuangan erat kaitannya dengan perilaku konsumsi masyarakat. Bagi individu yang memiliki pendapatan yang memadai masih sering mengalami masalah financial karena perilaku keuangan yang kurang bijak dalam pengambilan keputusan pembelanjaan keuangan, hal ini dapat dilihat dari masih banyak masyarakat bersikap konsumtif dari pada berinvestasi untuk masa depan.

Literasi keuangan (Financial Literacy) merupakan suatu keharusan bagi tiap individu agar terhindar dari masalah keuangan karena individu seringkali dihadapkan pada trade off yaitu situasi dimana seseorang harus mengorbankan salah satu kepentingan demi kepentingan lainnya. Menurut Robb \& Woodyard (2011) financial literacy yang cukup akan memberikan pengaruh positif terhadap perilaku keuangan seseorang, seperti mengatur atau mengalokasikan keuangannya dengan tepat.

Sikap konsumerisme yang menjadi kebiasaan saat ini membuat masyarakat kurang memiliki budaya menabung misalnya dalam hal berinvestasi. Masih banyak masyarakat yang belum menyadari pentingnya mempunyai manajemen keuangan di dalam kehidupan pribadinya karena masyarakat masih beranggapan bahwa perencanaan investasi keuangan pribadi hanya dilakukan oleh masyarakat yang memiliki pendapatan tinggi saja. Namun di sisi lain, masih terdapat juga individu yang memiliki pendapatan tinggi tetapi tidak mempunyai perencanaan investasi terhadap keuangan pribadinya dan kebanyakan pengalokasian dana ditujukan pada beberapa hal yaitu, investasi, tabungan dan konsumsi. Diantara tiga hal tersebut, jenis pengalokasian yang paling memberikan manfaat dimasa depan adalah investasi. Perencanaan investasi pada keuangan pribadi merupakan hal yang penting, karena hal tersebut merupakan proses belajar mandiri untuk mengatur keuangan di masa sekarang dan masa yang akan datang (Pritazahara, 2015). 


\section{A. Teori Literasi Keuangan}

\section{Theory of Planned Behavior (TPB)}

Mengembangkan Theory of Reasoned Action (TRA) menjadi sebuah teori lain, yaitu Theory of Planned Behavior (TPB) dan memperlihatkan hubungan dari perilaku-perilaku yang dimunculkan oleh individu untuk menanggapi sesuatu. Theory of Planned Behavior (TPB) menyatakan bahwa selain sikap terhadap tingkah laku dan norma-norma subjektif, individu juga mempertimbangkan kontrol tingkah laku yang dipersepsikan yaitu kemampuan mereka melakukan tindakan tersebut. teori ini menjelaskan bahwa adanya niat untuk berperilaku dapat menimbulkan perilaku yang ditampilkan oleh individu. (Ajzen, 1991).

Theory of Planned Behavior membagi tiga macam alasan yang dapat mempengaruhi tindaka yang diambil oleh individu, yaitu behavioral belief, yaitu keyakinan akan hasil dari suatu perilaku dan evaluasi atau penilaian terhadap hasil perilaku tersebut. keyakinan dan evaluasi atau penelitian terhadap hasil dari suatu perilaku tersebut kemudian akan membentuk variabel sikap (attitude). Kedua adalah normative belief, yaitu keyakinan individu terhadap harapan normative individu atau orang lain yang menjadi referensi seperti keluarga, teman, atasan, atau konsultan pajak untuk menyetujui atau menolak melakukan suatu perilaku yang diberikan.

\section{Theory of Reasoned Action (TRA)}

Theory of Reasoned Action digunakan sebagai acuan dalam teori literasi keuangan ini. Teori ini menggambarkan bahwa sikap memperngaruhi perilaku dalam pengambilan keputusan (Ajzen \& Fisbhein, 1975). Teori tersebut mengasumsikan juga bahwa manusia berprilaku dengan sadar dan tidak mempertimbangkan informasi yang tersedia. Faktor yang dapat dihubungkan oleh teori TRA yaitu sikap, keyakinan/niat, kehendak dan perilaku dalam pengambilan keputusan. Teori ini pula diketahui bahwa perilaku dipengaruhi oleh niat berperilaku individu 
terhadap perilaku tertentu yang menjadi faktor utama dari perilaku invidu. Sikap individu terhadap perilaku tersebut, norma subjektif dan perasaan individu tentang kemampuan mengontrol segala sesuatu yang mempengaruhi apabila hendak melakukan perilaku tersebut.

\section{Teori Atribusi}

Atribusi teori dapat dijelaskan ketika individu mengamati perilaku individu terhadap resiko. Teori ini juga tidak jauh beda dengan teori utility, dimana dalam penelitian ini perilaku seseorang dalam melakukan pengambilan keputusan investasi dapat menghindari terjadinya resiko (Christanti \& Mahastanti, 2011 dalam Arianti, 2020). Teori ini juga relevan untuk menjelaskan perilaku keuangan seseorang dalam mengelola keuangan dengan bijak.

\section{Theory Prospect}

Diyakini bahwa efek bersih dari keuntungan dan kerugian yang terlibat dengan masing-masing pilihan digabungakn untuk menyajikan evaluasi keseluruhan terhadap pilihan yang diinginkan. Para ahli cenderung menggunakan 'utilitas' untuk menggambarkan kenikmatan dan berpendapat bahwa kita lebih suka contoh yang memaksimalkan utilitas kita. Namun, penelitian telah menemukan bahwa kita tidak benar-benar memproses informasi dalam cara yang rasional. Kahneman \& Tversky (1979) mengemukakan teori prospek. Teori prospek berangkat dari analisis mengenai perilaku seseorang dalam pengambilan keputusan ekonomi di antara dua pilihan. Tidak seperti kebanyakan teori psikologi lainnya, karena dikembangkan bersama teori ekonomi, teori prospek memiliki dasar matematika yang kuat. Teori proskpek berfokus pada bagaimana keputusana nyata diambil. Teori prospek memiliki spesifikasi yaitu ekonomi berbasis perilaku yang menyatakan bahwa pelaku ekonomi tidaklah selamanya rasional. Dengan kata lain, dalam memandang 
pelaku ekonomi tidak hanya dilakukan pada sisi rasional atau tidak rasional saja melainkan pada aspek-aspek yang lebih luas. Ekonomi berbasis perilaku menekankan perilaku apa adanya dari pelaku ekonomi. Kahneman \& Tversky memulai penelitian terhadap perilaku manusia yang dianggap aneh dan kontradiktif dalam mengambil suatu keputusan dengan memberikan pilihan yang sama kepada dua subyek penelitian, dan kemudian dua subyek tersebut menunjukkan perilaku yang berbeda. Hal itu disebut Kahneman \& Tversky sebagai risk-aversion dan riskseeking behavior. Teori prospek menjelaskan bagaimana seseorang (investor) membuat keputusan dibawah kondisi resiko tertentu atau memilih diantara dua pilihan resiko dalam kondisi ketidakpastian. Ada beberapa aspek perilaku investor dalam memandang resiko yang dijelaskan dalam teori prospek, yaitu:

a. Loss aversion merupakan salah satu preferensi yang paling penting dalam teori keuangan keperilakuan. Aspek keperilakuan ini merupakan aspek yang membedakan dengan hipotesis pasar efisien. loss aversion menunjukkan keengganan investor untuk menderita kerugian. Seorang investor menunjukkan keengganan investor untuk menderita kerugian. Seorang investor cenderung menghindari kerugian dari pada memperoleh keuntungan.

b. Mental Accounting adalah kecenderungan orang untuk memisahkan uangnya ke dalam rekening berbeda berdasarkan berbagai kriteria subjektif, seperti berdasarkan sumber uang dan maksud dari setiap rekening. Menurut teori ini, individu menetapkan fungsi yang berbeda untuk setiap kelompok aset, yang sering memiliki pengaruh tidak rasional dan merugikan pada keputusan konsumsi dan perilaku lainnya.

c. Self-control menjelaskan sejauh mana investor dapat mengendalikan dirinya. Aspek perilaku ini digunakan untuk menjelaskan mengapa investor terus menjadi 
orang yang mengalami kerugian. Aspek perilaku ini juga dapat diartikan bahawa investor suka berinvestasi pada efek dimana mereka memiliki kemampuan untuk mengontrol investasinya. Dengan alasan ini investor lebih memilih saham yang memberikan dividen dibandingkan capital gain.

d. Regret aversion adalah kecenderungan investor untuk menghindari beberapa perilaku yang mungkin menjadikan dirinya tidak nyaman sesudahnya, meskipun dia percaya bahwa perilaku tersebut adalah yang terbaik. Hal ini karena ketika investor membuat keputusan yang salah, mereka akan merasa sakit dan menyesal atas keputusan tersebut. Semakin keputusan yang diambilnya adalah keputusan yang tidak konvensional, akan semakin besar penyesalannya. Dasar lain dari teori prospek adalah fungsi nilai. Fungsi nilai berbeda dari fungsi utilitas diharapkan teori utilitas karena titik referensi, yang ditentukan oleh kesan subjektif individu.

Tentunya setalah mempelajari suatu hal kita akan mendapatkan manfaat atas pelajaran tersebut. Begitu pula dengan perilaku keuangan apabila memahaminya secara benar. Terdapat manfaat yang dapat diperoleh dari memahami perilaku keuangan yaitu :

a. Untuk dunia akademik atau perkembangan dari ilmu ekonomi, kehadiran ekonomi berbasis perilaku serta perkembangan merupakan suatu terobosan penting. Dikatakan merupakan suatu terobosan penting karena didalamnya terdapat 'petunjuk' bahwa selama ini ilmu ekonomi terkesan menyepelekan faktor-faktor psikologi. Selain itu, dengan memasukkan faktor-faktor yang lebih luas cakupannya akan sangat membantu dalam memahami perilaku pelaku ekonomi yang menyimpang. Yang mana hal ini membuka peluang untuk semakin banyaknya ditemukan pengetahuan baru yang kemudian akan memperkaya ilmu ekonomi. 
b. Bagi pelaku ekonomi dalam melakukan kegiatan ekonominya. Kehadiran ekonomi berbasis perilaku dinilai dapat amat membantu untuk bagaimana pelaku ekonomi memahami perilakunya sendiri. Bagaimana pelaku ekonomi dapat memahami faktor-faktor seperti aspek kepribadian yang mencakup emosional, mood, suasana hati dan lainnya turut memberikan pengaruh terhadap perilaku yang menyimpang dari yang diharapkan. Alhasil, setiap orang terbantukan dalam mengendalikan diri asalkan ada niat yang kokoh untuk mereduksi penyimpangan perilaku tersebut.

\section{B. Pengertian Literasi Keuangan}

Terdapat dinamika mengenai konsep literasi keuangan di berbagai negara sehingga pengertian literasi keuangan di dalam SNLKI (2013) perlu disesuaikan. Penyesuaian ini dilakukan oleh OJK baik dalam SNLKI 7.1 LITERASI DAN INKLUSI KEUANGAN (Revisit 2017) maupun regulasi yang mengatur mengenai upaya peningkatan literasi dan inklusi keuangan. Penyempurnaan pengertian literasi keuangan dilakukan dengan menambahkan aspek sikap dan perilaku keuangan di samping pengetahuan, keterampilan dan keyakinan terhadap lembaga, produk dan layanan jasa keuangan. Secara lengkap pengertian dimaksud menjadi Literasi keuangan merupakan pengetahuan, keterampilan, dan keyakinan yang mempengaruhi sikap dan perilaku untuk meningkatkan kualitas pengambilan keputusan dan pengelolaan keuangan dalam rangka mencapai kesejahteraan.

Aspek sikap dan perilaku keuangan juga menjadi perhatian berbagai negara pada saat merevisi strategi nasional literasi keuangan mereka. Sikap dan perilaku keuangan tersebut memberikan gambaran bahwa literasi keuangan bukan hanya semata-mata mengetahui, terampil dalam memanfaatkan, dan meyakini lembaga, produk dan layanan jasa keuangan, melainkan juga mengenai pentingnya perubahan sikap dan perilaku keuangan seseorang agar hidup lebih sejahtera. Alasan yang mendasari perlunya aspek sikap 
dan perilaku keuangan dalam literasi keuangan adalah program literasi keuangan yang hanya mengandalkan pendekatan pengetahuan saja tidak dapat mengubah perilaku seseorang apabila mereka tidak memiliki sikap dan motivasi yang sesuai (World Bank, 2016). Sementara itu, perilaku merupakan realisasi dari sikap. Sikap dan perilaku keuangan dimaksud dapat mendorong seseorang untuk menentukan tujuan keuangan, memiliki perencanaan keuangan, mengambil keputusan keuangan dan mengelola keuangan dengan lebih baik guna mencapai kesejahteraan.

Literasi keuangan (Financial Literacy) yang berkaitan dengan kompetensi seseorang untuk mengelola keuangan. Definisi literasi finansial menurut Vitt et. al. (dalam Huston, 2010):

Personal financial literacy is the ability to read, analyze, manage and communicate about the personal financial condition that affect material well-being. It includes the ability to discern financial choices, discuss money and financial issues without (or despite) discomfort, plan for the future and respond competently to life events that affect everyday financial decisions, including events in the general economy"

Literasi finansial terjadi ketika individu memiliki sekumpulan keahlian dan kemampuan yang membuat orang tersebut mampu memanfaatkan sumber daya yang ada untuk mencapai tujuan. Huston (2010) menyatakan bahwa pengetahuan finansial merupakan dimensi yang tidak terpisahkan dari literasi finansial, namun belum

Menurut Sabri (2011) mendefinisikan melek finansial dengan tindakan mengetahui fakta-fakta dan pengertian yang diperlukan untuk mengelola keuangan pribadi sehingga berhasil mengelola keuangan dengan baik. Sedangkan menurut Kim (2001) dalam Sabri (2011) literasi keuangan adalah pengetahuan dasar bahwa orang perlu untuk bertahan hidup dalam masyarakat modern. Pengetahuan dasar ini melibatkan, mengetahui dan memahami prinsip-prinsip kompleks dalam melakukan pembelanjaan, menabung, dan berinvestasi. 
Warsono (2010) dalam rangka mencapai kemerdekaan keuangan, pengetahuan dan implementasi atas praktik keuangan pribadi yang sehat, idealnya perlu dipunyai dan dilakukan oleh setiap orang. Sejauhmana pengetahuan dan implementasi seseorang atau masyarakat dalam mengelola keuangan pribadinya ini sering dikenal sebagai literasi (kemelekan) keuangan (financial literacy).

Nagy \& Obenberger dalam Christanti \& Mahastanti (2011) menyebutkan bahwa personal financial needs didapat berdasarkan pengalaman investor dalam melihat nilai investasi dan perhitungan pada pengeluaran konsumsi sebagai seorang yang sungguh independen yang meliputi informasi tentang target hasil dari investasi untuk memenuhi keuangan pribadi, estimasi dana untuk investasi, keinginan diversifikasi, melihat kembali kinerja portofolio saham yang dimiliki di masa yang lalu.

Dari berbagai pengertian diatas, dapat disimpulkan bahwa literasi keuangan adalah kemampuan seseorang untuk mengetahui keuangan secara umum, dimana pengetahuan tersebut mencakup tabungan, investasi, hutang, asuransi serta perangkat keuangan lainnya. Selain itu, Remund (2010) mendefinisikan financial literacy sebagai, ukuran sejauh mana seseorang memahami kunci konsep keuangan, memiliki kemampuan serta percaya diri untuk mengelola keuangan pribadi dengan tepat, baik perencanaan keuangan jangka pendek maupun jangka panjang serta sadar terhadap perubahan kondisi ekonomi.

Kecerdasan finansial merupakan salah satu aspek penting dalam kehidupan saat ini. Kecerdasan finansial adalah kecerdasan dalam mengelola aset pribadi (Widayati, 2012). Individu harus memiliki suatu pengetahuan dan keterampilan untuk mengelola sumber keuangan pribadinya secara efektif demi kesejahteraannya. Selain menetapkan keputusan keuangan jangka pendek seperti tabungan dan pinjaman, individu juga harus memikirkan keputusan keuangan jangka panjang seperti perencanaan pensiun dan perencanaan 
pendidikan untuk anak-anaknya.

Selanjutnya, Bhushan \& Medury (2013) Literasi keuangan adalah kemampuan untuk membuat penilaian informasi dan mengambil keputusan yang efektif tentang penggunaan dan pengelolaan uang. Literasi keuangan merupakan kombinasi dari kemampuan individu, pengetahuan, sikap dan akhirnya perilaku individu yang berhubungan dengan uang. Literasi keuangan juga secara langsung berkorelasi dengan perilaku keuangan yang positif seperti pembayaran tagihan tepat waktu, angsuran pinjaman, tabungan sebelum habis dan menggunakan kartu kredit secara bijaksana. Literasi keuangan membantu untuk meningkatkan kualitas pelayanan keuangan dan memberikan kontribusi terhadap pertumbuhan ekonomi dan pembangunan suatu negara. Semakin meningkatnya kompleksitas ekonomi, kebutuhan individu dan produk keuangan, individu harus memiliki literasi keuangan untuk mengatur keuangan pribadinya. Pengetahuan tentang keuangan sangat penting bagi seorang individu, agar mereka tidak salah dalam membuat keputusan keuangan mereka. Pengetahuan tentang keuangan yang kurang, mengakibatkan kerugian bagi individu, baik akibat dari inflasi, penurunan kondisi perekonomian baik dalam negeri maupun luar negeri, atau berkembangnya sistem perekonomian.

Keterbatasan finansial dapat menyebabkan stress, dan rendahnya kepercayaan diri. Adanya pengetahuan keuangan dan literasi keuangan akan membantu individu dalam mengatur perencanaan keuangan pribadi, sehingga individu tersebut bisa memaksimalkan nilai waktu uang dan keuntungan yang diperoleh oleh individu akan semakin besar dan akan meningkatkan taraf kehidupannya. Bhushan \& Medury (2013) menjelaskan literasi keuangan sangat penting karena beberapa alasan. Konsumen yang memiliki literasi keuangan bisa melalui masa-masa keuangan yang sulit karena faktanya bahwa mereka mungkin memiliki akumulasi tabungan, membeli asuransi dan diversifikasi investasi mereka. 
Literasi keuangan juga secara langsung berkorelasi dengan perilaku keuangan yang positif seperti pembayaran tagihan tepat waktu, angsuran pinjaman, tabungan sebelum habis dan menggunakan kartu kredit secara bijaksana. Literasi keuangan membantu untuk meningkatkan kualitas pelayanan keuangan dan memberikan kontribusi terhadap pertumbuhan ekonomi dan pembangunan suatu negara. Semakin meningkatnya kompleksitas ekonomi, kebutuhan individu dan produk keuangan, individu harus memiliki literasi keuangan untuk mengatur keuangan pribadinya. Pengetahuan tentang keuangan sangat penting bagi seorang individu, agar mereka tidak salah dalam membuat keputusan keuangan mereka. Pengetahuan tentang keuangan yang kurang, mengakibatkan kerugian bagi individu, baik akibat dari inflasi, penurunan kondisi perekonomian baik dalam negeri maupun luar negeri, atau berkembangnya sistem perekonomian.

Nidar \& Bestari (2012) menjelaskan bahwa perekonomian nasional tidak akan berpengaruh pada krisis keuangan global jika masyarakat memahami sistem keuangan. Kesalahpahaman menyebabkan banyak orang mengalami kerugian keuangan, sebagai akibat dari pengeluaran yang boros dan konsumsi, tidak bijaksana dalam penggunaan kartu kredit, dan menghitung perbedaan antara kredit konsumen dan pinjaman bank. Selain itu, kurangnya pengetahuan tentang keuangan menyebabkan seseorang sulit untuk melakukan investasi atau mengakses ke pasar keuangan.

\section{Aspek Literasi Keuangan}

Literasi keuangan mencakup banyak aspek yang perlu diukur. Literasi keuangan telah berkembang dalam beberapa tahun terakhir dan mendapatkan perhatian yang lebih, khususnya pada negara-negara maju. Istilah literasi keuangan adalah kemampuan seorang individu untuk mengambil keputusan dalam hal pengaturan keuangan pribadinya. Chen \& Volpe (1998) dalam Margaretha (2015) membagi literasi keuangan menjadi empat aspek, yaitu: 
a. Pengetahuan keuangan dasar (basic financial knowledge) yang mencakup pengeluaran, pendapatan, aset, hutang, ekuitas, dan risiko. Pengetahuan dasar ini biasanya berhubungan dengan pengambilan keputusan dalam melakukan investasi atau pembiayaan yang bisa mempengaruhi perilaku seseorang dalam mengelola uang yang dimiliki.

b. Simpanan dan pinjaman (saving and borrowing), merupakan produk perbankan yang lebih dikenal sebagai tabungan dan kredit. Tabungan merupakan sejumlah uang yang disimpan untuk kebutuhan di masa depan. Seseorang yang memiliki pendapatan yang lebih tinggi dibandingkan pengeluarannya akan cenderung menyimpan sisa uangnya tersebut untuk kebutuhan di masa depan.

c. Proteksi atau asuransi (insurance) merupakan suatu bentuk perlindungan secara finansial yang bisa dilakukan dalam bentuk asuransi jiwa, asuransi properti, asuransi pendidikan, dan asuransi kesehatan. Tujuan dari proteksi adalah untuk mendapatkan ganti rugi apabila terjadi hal yang tidak terduga seperti kematian, kehilangan, kecelakaan, atau kerusakan. Untuk mendapatkan asuransi yang mudah dan murah serta tidak berbelit, masyarakat cukup datang ke gerai toko ritel waralaba tak jauh dari rumah. Polisnya sederhana, ringkas, tidak berbelit. Secara umum, hampir semua jenis produk asuransi yang ada, baik konvensional maupun syariah, dapat menjadi asuransi mikro. Jenisnya beragam. Ada asuransi jiwa mikro, asuransi mikro demam berdarah, asuransi kecelakaan, asuransi tani, asuransi nelayan, asuransi kebakaran, dan masih banyak lagi. Yang membedakan produk asuransi mikro adalah karakteristiknya yang khas. Sesuai namanya, produk asuransi mikro tentunya sederhana, mudah, ekonomis, dan segera. Produk asuransi mikro haruslah mudah dijangkau oleh masyarakat berpenghasilan rendah, baik 
dari sisi ketersediaan maupun harga. Umumnya, premi yang ditetapkan untuk satu produk asuransi mikro tidak lebih dari Rp.50.000. Bahkan ada pula yang hanya Rp.20.000 seperti produk asuransi Capital Eka Proteksi atau Cakap dari PT. Capital Life Indonesia, yang merupakan produk asuransi mikro dengan premi tunggal seharga Rp.20.000 artinya hanya dengan membayar Rp.20.000 sebanyak satu kali, nasabah bisa memperoleh perlindungan pertanggungan jiwa selama 6 bulan. Investasi merupakan suatu bentuk kegiatan penanaman dana atau aset dengan tujuan untuk memperoleh keuntungan di waktu yang akan datang. Bentuk investasi bisa berupa aset riil (properti atau emas), aset keuangan (saham, deposito, obligasi, dan aset keuangan lainnya), dan lain-lain.

d. Investasi merupakan suatu bentuk kegiatan penanaman dana atau aset dengan tujuan untuk memperoleh keuntungan di waktu yang akan datang. Bentuk investasi bisa berupa aset riil (properti atau emas), aset keuangan (saham, deposito, obligasi, dan aset keuangan lainnya), dan lain-lain. 